\title{
Law Enforcement against Criminal Action with Fingerprint Evidence
}

\author{
Wilddan Auliya ${ }^{*}$ and Jawade Hafidz ${ }^{* *}$ \\ *) Ditreskrimum of Central Java Regional Police, E-mail: wildanauliya1@gmail.com \\ ${ }^{* *}$ Faculty of Law, Universitas Islam Sultan Agung (UNISSULA) Semarang
}

\begin{abstract}
The objectives of this study are 1) To study and analyze law enforcement against the perpetrator of the crime of theft using fingerprint evidence. 2) To analyze the factors that influence law enforcement against the perpetrators of criminal acts of theft. 3) To formulate should be obstacles and solutions in law enforcement against perpetrators of criminal acts of theft with fingerprint evidence in the future. This research method uses empirical juridical research. The results of the study concluded that: 1) Law enforcement against perpetrators of criminal acts of theft with fingerprint evidence uses 2 (two) means, namely: a) Non-penal means are law enforcement against criminal acts using the means non penal includes the use of social facilities to improve certain social conditions, but indirectly affects efforts to prevent crime. b) Penal facility Penal facility is the prevention of crime by using criminal law and for studying fingerprints or often referred to as evidence which is one part of assistive science used by the police in taking and studying fingerprints. 2) The factors that influence law enforcement on the eradication of criminal acts of theft consist of internal and external factors. Internal factors consist of social inequality, economic inequality, injustice. 3) Constraints and solutions in law enforcement against perpetrators of criminal acts of theft with fingerprint evidence a) the obstacles faced are legal aspects and aspects of investigators b) Solutions in law enforcement against perpetrators of criminal acts of theft with fingerprint evidence require a role/action Indonesian Police in law enforcement, especially in handling criminal acts of theft with fingerprint evidence (dactyloscopy), it can be seen that the police action in dealing with criminal acts of theft in the future is besides maintaining its procedures (Permanent Program), namely chain patrols, early detection, handling of TKP that were attacked by the Police, Polwiltabes and Central Java Regional Police/as well as case titles until the case is revealed.

Keywords: Enforcement; Crime; Fingerprint; Evidence.
\end{abstract}

\section{Introduction}

In the life of the nation and the state, security is a determining factor in the life of the nation and state in implementing a sovereign and authoritative government, which is the main condition that supports justice and prosperity as well as life that exists in the civil society system based on Pancasila and the 1945 Constitution of the Republic. Domestically, the Police carry out law enforcement efforts through a process of criminal investigation and investigation, acting as regulated in Act No. 2 of 2002 concerning the Indonesian National Police. ${ }^{1}$

The factors behind the weighted theft crime are economic factors, low levels of education, increased unemployment, lack of legal awareness, loosening of family and

\footnotetext{
${ }^{1} \mathrm{Ni}$ Made Srinitri and Umar Ma'ruf, "Progressivity Of Criminal Handling Fraud And Disease By The Directorate Of The General Criminal Researcher Of Central Java Regional Police (POLDA)", Jurnal Daulat Hukum Volume 3 Issue 1, March 2020 ISSN: 2614-560X
} 
social ties. ${ }^{2}$ There are no religious, moral, moral or legal norms that are harmful to the livelihoods and livelihoods of the community, nation and state. Weighted theft is one of the societal diseases that regenerate and harm others.

Fingerprints are personal identities that are natural, unchanging and not the same for everyone. Fingerprint is also a technology that can be used to identify a person. In the field of police, fingerprints are known as latent. Fingerprints are valid evidence, namely as evidence for expert testimony (in accordance with Article 184 paragraph (1) point (b) of the Criminal Procedure Code (KUHAP). The purpose of this study was to analyze law enforcement against perpetrators of criminal acts of theft with fingerprint evidence as well as obstacles and solutions in law enforcement.

\section{Research Methods}

This approach method uses empirical juridical method ${ }^{3}$ and the type of research used is qualitative research. ${ }^{4}$ Secondary data in this study was carried out by means of literature study. The research specification used in this research is descriptive analytical. ${ }^{5}$ Data collection techniques include 1) Literature Study of this research uses Library Research. 2) Observation data collection technique was carried out by observation and interviews. 3) Interviews In this study, interviews were conducted with informants in a free guided manner 6 . Samples were taken using purposive sampling method. The data analysis method used is descriptive qualitative?.

\section{Results and Discussion}

\subsection{Law Enf orcement against Perpetrators of The Crime of Theft By Objecting With Fingerprint Evidence In The Legal Area Of Central Java Regional Police}

In order to achieve the objectives of criminal procedural law, other knowledge provisions are needed for law enforcement officials to be able to assist in finding material truths. Among other things, the science of studying fingerprints or often referred to as dactyloscopy, which is one part of the assistive science used by the police in taking and studying fingerprints. In practice this science is mostly used, namely to find out who the real perpetrator/person is or at least was at the scene of the crime. The results of this dactyloscopy technique are quite good, because basically in the world there are no identical fingerprints.

\footnotetext{
2 http://beritasore.com/2012/01/03/pengangguran-picu-kejahatan-di-medan/, accessed on April 2, 2020

${ }^{3}$ Soekanto, Soerjono \& Sri Mamudji. (2001). Penelitian Hukum Normatif (Suatu Tinjauan Singkat. Jakarta: Rajawali Press. p.3-14

4Ediwarman. (2010). Monograf, Metodologi Penelitian Hukum. Medan: Postgraduate Program Univ. Muhammadiyah of North Sumatra. p. 24

${ }^{5}$ Sugiyono. (2014). Metode Penelitian Kualitatif dan R\&D. Alfabeta. Bandung. p.27

${ }^{6} \mathrm{http}: / /$ www.bahasaindonesiaku.net accessed on 13 August 2020

${ }^{7}$ Dkk, Afifuddin. (2009). Metodologi Penelitian Kualitatif. Bandung: p.15
} 
In every crime that occurs in society, not all of these crimes can be easily proven or determined who the perpetrator of the crime is. ${ }^{8}$ Dactyloscopy is usually used for major crimes and minimal evidence remains and requires special expertise to determine the culprit.

\subsection{Factors Affecting Law Enforcement Against The Crime Of Theft In The Legal Territory of The Central Java Regional Police}

The causes of crime, in particular the theft of rights, consist of internal and external factors. This factor can be said to be quite complex and varied. ${ }^{9}$

\subsubsection{Internal Factors}

- Educational Factor; The education factor is one of the driving factors for a person to commit a criminal act of land management without rights. This is due to their lack of knowledge of things such as the rules of social life.

- Individual Factors; Someone whose behavior is good will cause that person to get respect from society, but on the other hand, if someone behaves badly then that person will cause chaos in society.

\subsubsection{External Factors}

- Economic Factors; Economic problems are the biggest reason for perpetrators of criminal acts of theft to commit their actions.

- Environmental factor; Many things make the environment a factor in the occurrence of a criminal act of theft. A person who lives/lives in an environment that is conducive to theft, then one day he will also commit the crime of theft.

- Law Enforcement Factors; The less than optimal application of the criminal law makes the perpetrators indifferent to commit criminal acts. Difficult to achieve justice for victims makes people gradually turn away or do not believe in the state as a protector of citizens' rights;

- Global Development Factors (Technology); Advances in technology, especially the mass media, also influence someone to do evil. The mass media provide stimulation to a person's thoughts in social life.

\subsection{Constraints and Solutions in Law Enforcement Against The Crime Of Theft With Fingerprint Evidence In The Future}

\subsubsection{Constraints faced in Law Enforcement Against Perpetrators of Crime of Theft} Using Fingerprint Evidence in the Future

Legal Aspects; Legislation still does not have a legal rule regarding the function of fingerprints as valid evidence only as a means of evidence which must be proven according to the expert's statement based on Article 184 KUHAP. In KUHAP and KUHP, it is clear about the criminal act of theft, but not for fingerprints, they can be functioned or searched for their identity when a person is 17 (seventeen years old)

\footnotetext{
${ }^{8}$ Mohamad Rofiqi, Crime Investigation on Theft by eighting with The Modus Of Prying Automated Teller Machine (ATM) in Jurisdiction Area of Central Java, Jurnal Daulat Hukum Volume 1 Issue 1, September 2018 ISSN: 2614-560X I Ibid
} 
because they have already recorded an E-KTP, fingerprints are difficult to find when the record is not recorded E-KTP and also committing a crime for the first time.

Investigator Aspects; Police investigators have an important role in efforts to tackle criminal acts of theft, where the ability of investigators is needed to uncover this case. The existence of the INAFIS (Indonesia Automatic Finger Print Identification System) unit within the Police proves that it takes a special investigator who has the ability to search and analyze the form of fingerprints because all fingerprints at the scene of a crime are often inaccurate or difficult to read. Therefore, a special education is needed to provide knowledge related to fingerprints to investigators who specifically handle a crime related to finding fingerprints at the crime scene location.

\subsubsection{Solutions in Law Enforcement Against The Crime Of Theft With Fingerprint Evidence In The Future}

In this case, law enforcement against perpetrators of criminal theft in the future requires the role/action of the Police in law enforcement of the Central Java Regional Police, especially in handling criminal acts of theft with fingerprint evidence, it can be seen that the actions of the Central Java Regional Police in handling criminal acts of theft in the future. What will come is besides maintaining its procedures (Fixed Program), namely chain patrols, jartup. Polmas, Kring Serse, early detection, handling of TKP that were attacked by the Police, Polwiltabes and Central Java Regional Police/as well as case titles until the case was revealed were also added by the National Police Chief's Jakstra called Grand Strategy of Indonesian Police. ${ }^{10}$

\section{Conclusion}

Law enforcement against the perpetrator of the crime of theft with fingerprint evidence in the jurisdiction of the Central Java Regional Police is by controlling or overcoming crime (criminal politics) using 2 (two) means, namely: Non-Penal Facilities, Penal Facilities. The factors that influence law enforcement against perpetrators of criminal acts of theft in the jurisdiction of the Central Java Regional Police consist of internal and external factors. Internal factors are those that occur from himself, while external factors are factors that are created from outside himself. This factor is said to be quite complex and varied. Social inequality, economic inequality, injustice, etc. Constraints and solutions in law enforcement against perpetrators of criminal acts of theft with fingerprint evidence in the future.

\section{References}

Journal:

[1] Mohamad Rofiqi, Crime Investigation on Theft by eighting with The Modus of Prying Automated Teller Machine (ATM) in Jurisdiction Area of Central Java, Jurnal Daulat Hukum Volume 1 Issue 1, September 2018 ISSN: 2614-560X 10Prodjodikoro, Wirjono. (2003). Tindak-Tindak Pidana Tertentu Di Indonesia. Bandung: Refika
Aditama. p.30 
[2] Ni Made Srinitri, Umar Ma'ruf, Progressivity Of Criminal Handling Fraud And Disease By The Directorate Of The General Criminal Researcher Of Central Java Regional Police, Jurnal Daulat Hukum Volume 3 Issue 1, March 2020 ISSN: 2614-560X

Books:

[1] Afifuddin, et.all. (2009). Metodologi Penelitian Kualitatif. Bandung

[2] Ediwarman. (2010). Monograf, Metodologi Penelitian Hukum. Medan: Postgraduate Program Univ. Muhammadiyah of North Sumatra

[3] Prodjodikoro, Wirjono. (2003). Tindak-Tindak Pidana Tertentu Di Indonesia. Bandung: Refika Aditama

[4] Soekanto, Soerjono \& Sri Mamudji. (2001). Penelitian Hukum Normatif (Suatu Tinjauan Singkat. Jakarta: Rajawali Press

[5] Sugiyono. (2014). Metode Penelitian Kualitatif dan R\&D. Alfabeta. Bandung

\section{Regulations:}

[1] Act No. 2 of 2002 concerning the Indonesian National Police

[2] Act No. 8 of 1981 concerning the Criminal Procedure Code

[3] Act No. 1 of 1946 concerning the Criminal Code

[4] Supreme Court Regulation Number 2 of 2012 concerning Adjustment of Limits of Minor Crime and Amount of Fines in the Criminal Code

[5] Act No. 16 of 2004 concerning the Republic of Indonesia Attorney General's Office

[6] Decision of Kapolri No. 10/2009 concerning Procedures and Requirements for a Criminalistic Technical Examination Request at the Venue and Criminalistic Evidence Laboratory to the Forensic Laboratory of the Indonesian National Police.

[7] Technical Guidance No. Pol: Juknis/02/III/2000 concerning Chemical Development of Latent Fingerprints

Internet:

[1] http://beritasore.com/2012/01/03/pengangguran-picu-kejahatan-di-medan/ , accessed on April 2, 2020

[2] http://www.bahasaindonesiaku.net accessed on 13 August 2020 